\title{
GAMBARAN PENGETAHUAN PENYAKIT CACINGAN (HELMINTHIASIS) PADA WALI MURID SDN 1, 2, 3, DAN 4 MULYOAGUNG, KECAMATAN DAU, KABUPATEN MALANG, JAWA TIMUR
}

\author{
Dhia Irfan Hanif \\ Moch Yunus \\ Rara Warih Gayatri \\ Universitas Negeri Malang \\ e-mail: dhiairfanhanif@gmail.com
}

\begin{abstract}
WHO (2016) said the helminthiasis is an infection of the intestinal parasites of the Nematodes are transmitted through the ground, Soil Transmitted Helminths or (STH). WHO (2016) reported more than 2 billion people are infected with helminthiasis. According to Indonesia Ministry of Health (2004), the prevalence of helminthiasis in children of the primary school in 2003 amounting to 33\% increasing and in 2004 became 46,8\%. Indonesia Ministry of Health (2005) presents results of survey of helminthiais in elementary school showed the prevalence of approximately 60\%-80\%. The purpose of this research is to know the description of the knowledge of the helminthiasis on caregivers SDN 1, 2, 3, and 4 Mulyoagung, Dau, Malang, East Java. This research uses descriptive methods (cross sectional) and quantitative approach. The population of the research was the entire caregivers $S D N$ 1,2,3, and 4 Mulyoagung a number of 685 people, with samples 253 people. Research instrument using a questionnaire based on the indicator of knowledge on health. Engineering data retrieval done by giving questionnaires to caregivers through the student and teacher. Data analysis using descriptive statistical analysis to determine the score of the questionnaire and determine the level of knowledge of caregivers. The results of the research in general, the description of the knowledge of the disease intestinal worms (helminthiasis) on caregivers SDN 1, 2, 3, and 4 Mulyoagung, Kecamatan Dau, Malang, East Java was less, with an average score of respondents 45,81.
\end{abstract}

Keywords: knowledge, helminthiasis, parents (caregivers)

\begin{abstract}
Abstrak: WHO (2016) mengatakan helminthiasis adalah infeksi cacing parasit usus dari golongan Nematoda usus yang ditularkan melalui tanah atau disebut Soil Transmitted Helminths (STH). WHO (2016) melaporkan lebih dari 2 miliar orang terinfeksi cacingan. Menurut DEPKES RI (2004), prevalensi cacingan pada anak sekolah dasar pada tahun 2003 sebesar 33\% dan meningkat pada tahun 2004 menjadi 46,8\%. DEPKES RI (2005) memaparkan hasil survei cacingan di sekolah dasar menunjukan prevalensi sekitar $60 \%-80 \%$. Tujuan dari penelitian ini adalah untuk mengetahui gambaran pengetahuan helminthiasis pada wali murid SDN 1, 2, 3, dan 4 Mulyoagung, Kecamatan Dau, Kabupaten Malang, Jawa Timur. Penelitian ini merupakan penelitian deskriptif dengan pendekatan cross sectional. Populasi penelitian adalah seluruh wali murid SDN 1, 2, 3, dan 4 Mulyoagung sejumlah 685 orang, dengan sampel sejumlah 253 orang. Instrumen penelitian menggunakan kuesioner untuk mengetahui pengetahuan terhadap kesehatan. Teknik pengambilan data dilakukan dengan memberikan kuesioner kepada wali murid melalui siswa dan guru. Analisis data menggunakan analisis statistik deskriptif untuk menentukan skor dari kuesioner dan menentukan tingkat pengetahuan wali murid. Hasil penelitian secara umum, gambaran pengetahuan penyakit cacingan (helminthiasis) pada wali murid SDN 1, 2, 3, dan 4 Mulyoagung, Kecamatan Dau, Kabupaten Malang, Jawa Timur adalah kurang, dengan skor ratarata responden 45,81 .
\end{abstract}

Kata kunci: pengetahuan, cacingan (helminthiasis), wali murid

World Health Organization (2016) menjelaskan bahwa cacingan adalah infeksi cacing parasit usus dari golongan Nematoda usus yang ditularkan melalui tanah, atau disebut Soil Transmitted Helminths (STH). STH yang sering ditemukan pada manusia adalah Ascaris lumbricoides, Necator americanus, 
Ancylostoma duodenale, Trichuris trichiura, dan Strongiloides stercoralis

(WHO, 2016). Sumanto (2010) menjelaskan jika penyakit cacingan adalah contoh lain dari penyakit parasitik yang mulai terabaikan atau Neglacted Tropical Desease (NTD).

Kasus infeksi oleh STH terjadi karena tertelannya telur cacing dari tanah atau tertelannya larva aktif yang ada di tanah melalui kulit (WHO, 2016). Umar (2008) mengatakan, penyakit cacingan menimbulkan dampak yang besar pada manusia karena mempengaruhi pemasukan (intake),

pencernaan (digestif), penyerapan (absorbsi), dan metabolisme makanan. Akibat yang ditimbulkan dari infeksi cacing berupa kerugian zat gizi karbohidrat dan protein (Umar, 2008). Masalah lain yang ditimbulkan adalah kekurangan darah, menghambat perkembangan fisik, perkembangan mental, kemunduran intelektual, dan menurunkan imunitas tubuh pada anakanak (DEPKES RI, 2004).

WHO (2016) melaporkan lebih dari 2 miliar orang terinfeksi penyakit cacingan. Menurut DEPKES RI (2004), angka nasional prevalensi cacingan pada anak sekolah dasar pada tahun 2003 sebesar 33\%. Pada tahun 2004, prevalensi penyakit cacingan meningkat menjadi 46,8\% (DEPKES RI, 2006). Pada tahun 2005, survei infeksi cacingan di sekolah dasar di beberapa provinsi menunjukan prevalensi sekitar 60\%80\% (DEPKES RI, 2005).

Faktor-faktor risiko penyebab tingginya prevalensi penyakit cacingan adalah rendahnya tingkat sanitasi pribadi (Perilaku Hidup Bersih Sehat) dan buruknya sanitasi lingkungan (Umar, 2008). Perilaku seperti tidak mencuci tangan sebelum makan dan setelah buang air besar (BAB), tidak menjaga kebersihan kuku, perilaku jajan di sembarang tempat yang kebersihannya tidak dikontrol, perilaku BAB tidak di WC yang menyebabkan pencemaran tanah dan lingkungan oleh feses yang mengandung telur cacing, serta kurangnya ketersediaan sumber air bersih adalah beberapa kondisi sebagai penyebab infeksi cacingan (Astuty dkk, 2012).

WHO (2011) mengatakan di dalam konferensi internasional kesehatan pertama tahun 1986 (Ottawa Charter) dijelaskan bahwa ada sembilan prasyarat (pre requisites) yang mempengaruhi kesehatan, salah satunya adalah knowledge atau pengetahuan. Badan Pembangunan PBB atau UNDP (2011) memberikan tiga indikator pembangunan manusia yang disusun dalam Human Development Index atau Indeks Pembangunan Manusia yakni pengetahuan, kesehatan, dan ekonomi. Ketiga hal tersebut bukan hanya saling terkait dan mempengaruhi, namun juga saling melengkapi dalam membentuk kualitas hidup manusia (Notoatmodjo, 2012). Tingkat pengetahuan orang tua akan permasalahan kesehatan dapat mempengaruhi perilaku dan tingkat kesehatan anak (Notoatmodjo, 2012).

Faridan (2013) mengatakan bahwa penyakit cacingan paling banyak terjadi pada anak usia sekolah dasar. Hal itu disebabkan anak pada usia tersebut sering melakukan kontak dengan tanah. Kasus cacingan terbanyak dari golongan cacing Ascariasis (Faridan, 2013). DEPKES RI (2006) menyatakan bahwa anak usia sekolah dasar merupakan golongan tertinggi terinfeksi cacing yang penularannya melalui tanah.

Tujuan dari penelitian ini adalah untuk mengetahui gambaran pengetahuan penyakit cacingan (helminthiasis) pada wali murid SDN 1, 2, 3, dan 4 Mulyoagung, Kecamatan Dau, Kabupaten Malang, Jawa Timur.

\section{METODE}

Penelitian ini merupakan penelitian deskriptif dengan pendekatan cross sectional. Penelitian ini digunakan untuk mengetahui gambaran pengetahuan penyakit cacingan (helminthiasis) pada wali murid SDN 1, 2, 3, dan 4 Mulyoagung, Kecamatan Dau, Kabupaten Malang, Jawa Timur. Populasi penelitian adalah seluruh wali murid SDN 1, 2, 3, dan 4 
Mulyoagung Kecamatan Dau,

Kabupaten Malang, Jawa Timur sejumlah 685 orang dengan ampel sejumlah 253 dengan pengambilan

sampel menggunakan teknik proportional random sampling.

Pada sampel penelitian ini terdapat kriteria inklusi dan eksklusi yang digunakan. Kriteria inklusi adalah wali murid SDN 1, 2, 3, dan 4

Mulyoagung, Kecamatan Dau, Kabupaten Malang, Jawa Timur yang bersedia menjadi responden dan mengisi kuesioner dengan menyetujui informed consent yang disediakan. Kriteria eksklusi adalah wali murid SDN 1, 2, 3, dan 4 Mulyoagung, Kecamatan Dau, Kabupaten Malang, Jawa Timur yang tidak bersedia menjadi responden dengan tidak menyetujui informed consent yang disediakan.

Instrumen dalam penelitian ini menggunakan kuesioner, untuk mengambil data primer yang digunakan dalam menggambarkan tingkat pengetahuan wali murid SDN 1, 2, 3, dan 4 Mulyoagung, Dau, Kabuaten Malang, Jawa Timur. Indikator-indikator yang dapat digunakan untuk mengetahui tingkat pengetahuan terhadap kesehatan (sakit dan penyakit) meliputi (Notoatmodjo, 2012):
1) Penyebab penyakit;

2) Faktor risiko penyakit;

3) Gejala dan tanda penyakit;

4) Patofisiologi penyakit;

5) Penatalaksanaan penyakit;

6) Pencegahan penyakit (termasuk imunisasi).

Dalam penelitian ini, ada dua langkah pengolahan data, yakni pengolahan data manual dan pengolahan data dengan komputer. Teknik analisis dalam penelitian ini adalah analisis statistik deskriptif dengan dengan

menggunakan aplikasi komputer. Analisis deskriptif dilakukan berdasarkan nilai atau skor akhir dari kuesioner, dengan kategori penilaian menurut Arikunto (2007), yaitu:

a. Baik: menjawab benar $76 \%-100 \%$ dari seluruh pertanyaan;

b. Cukup: menjawab benar 56\%-75\% dari seluruh pertanyaan;

c. Kurang: menjawab benar $40 \%-55 \%$ dari seluruh pertanyaan.

\section{HASIL}

Hasil analisis distribusi frekuensi skor rata-rata responden berdasarkan sekolah adalah sebagai berikut:

Tabel 1. Distribusi frekuensi skor rata-rata berdasarkan sekolah

\begin{tabular}{ccccc}
\hline No & Sekolah & Jumlah Responden & Skor (rata-rata) & Kategori (rata-rata) \\
\hline 1 & SDN 1 Mulyoagung & 96 & $48 \%$ & Kurang \\
\hline 2 & SDN 2 Mulyoagung & 41 & $39 \%$ & Kurang \\
\hline 3 & SDN 3 Mulyoagung & 72 & $48 \%$ & Kurang \\
\hline 4 & SDN 4 Mulyoagung & 43 & $41 \%$ & Kurang \\
\hline & Total & 253 & $45 \%$ & Kurang \\
\hline
\end{tabular}

Pada tabel diatas menunjukkan bahwa pengetahuan wali murid di SDN 1 Mulyoagung memiliki skor rata-rata sebesar $48 \%$ dengan kategori kurang, SDN 2 Mulyoagung memiliki skor ratarata sebesar 39\% dengan kategori kurang, SDN 3 Mulyoagung memiliki skor rata-rata sebesar $48 \%$ dengan

kategori kurang, dan SDN 4 Mulyoagung memiliki skor rata-rata sebesar $41 \%$ dengan kategori kurang.
Rata-rata pengetahuan wali murid SDN 1, 2, 3, dan 4 Mulyoagung, Kecamatan Dau, Kabupaten Malang, Jawa Timur adalah 45,81. Sehingga wali murid SDN 1, 2, 3, dan 4 Mulyoagung, Kecamatan Dau, Kabupaten Malang, Jawa Timur memiliki tingkat pengetahuan dengan kategori kurang, yakni diantara $40 \%$ $55 \%$.

Hasil pengetahuan penyakit cacingan (helminthiasis) wali murid 


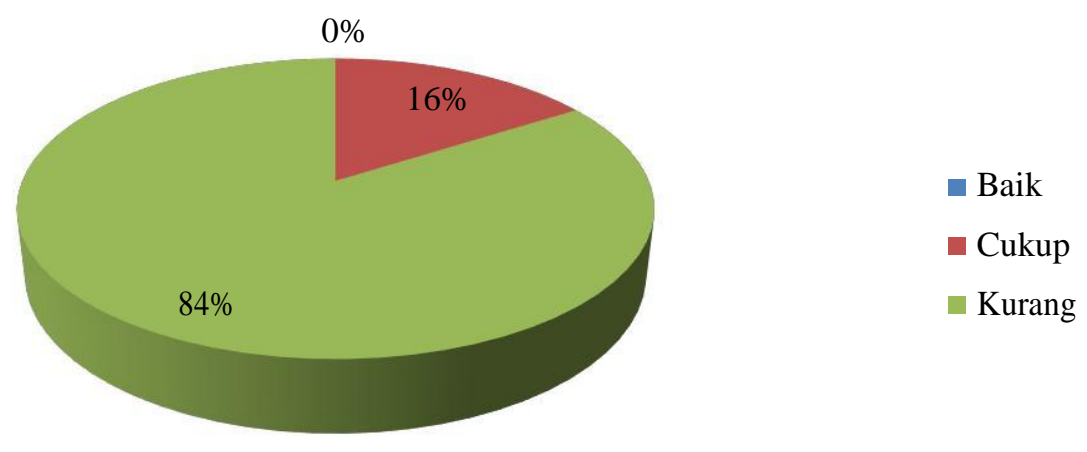

Gambar 1. Grafik Pengetahuan penyakit cacingan (helminthiasis) wali murid SDN 1, 2, 3, dan 4 Mulyoagung, Kecamatan Dau, Kabupaten Malang, Jawa Timur

Keterangan:

Kurang: 212 responden dari 253 responden total

Cukup: 41 responden dari 253 responden total

Baik: 0 responden dari 253 responden total

\section{PEMBAHASAN}

\section{Penyebab penyakit cacingan}

Pada kuesioner nomer 1, persentase jawaban benar responden sebesar $77 \%$. Hasil ini menggambarkan bahwa wali murid SDN 1, 2, 3, dan 4 Mulyoagung telah mengetahui bahwa nyamuk bukanlah hewan perantara penyebaran penyakit cacingan.

Penyebab penyakit cacingan adalah infeksi cacing parasit usus dari golongan Nematoda usus (WHO, 2016). Cacing parasit usus tersebut diantaranya adalah cacing gelang (Ascaris lumbricoides/ roundworm), cacing

tambang (Necator americanus, Ancylostoma duodenale/hookworm), dan cacing cambuk (Trichuris trichiura) (Faridan, 2013). Cacing penyebab penyakit cacingan tersebut dapat menembus kulit dan masuk kedalam tubuh anak atau masuk melalui hewan perantara. Binatang seperti tikus, lalat, dan kecoa merupakan hewanhewan yang dapat menjadi vektor penyakit cacingan. Menurut Herdiman (2007), ketiga binatang tersebut dapat membawa telur infektif cacing.

WHO (2006) mengatakan bahwa rantai penularan STH dapat dipengaruhi oleh vektor, yakni serangga khusunya lalat. Astuty dkk (2012) menambahkan bahwa sangat mungkin terdapat telur cacing pada makanan melalui lalat yang hinggap pada makanan tersebut, dikarenakan lalat cenderung hinggap pada lingkungan yang menjadi lokasi perkembangan telur dan larva cacing.

Binatang-binatang pembawa telur infektif cacing tersebut biasanya memiliki perilaku yang cenderung untuk melakukan kontak dengan kotoran manusia dan hewan (Ginting, 2008). Kotoran manusia dan hewan adalah sumber penyebaran penyakit cacingan. Hewan seperti tikus dan kecoa adalah hewan dengan perilaku dan habitat dekat dengan lingkungan dimana terdapat kotoran manusia dan hewan, sehingga dapat menjadi vektor penyebaran penyebab penyakit cacingan (Herdiman, 2007). Kedua hewan tersebut juga hidup dekat dengan lingkungan manusia dan tidak jarang melakukan kontak langsung dengan makanan dan minuman manusia (Ginting, 2008). 
Faktor risiko penyakit cacingan Sanitasi Lingkungan

Pada kuesioner nomer 6, persentase jawaban benar responden sebesar $72 \%$. Hal ini menggambarkan bahwa pengetahuan wali murid SDN 1, 2, 3, dan 4 Mulyoagung cukup baik dengan mengetahui bahwa telur cacing tidak hanya terdapat pada kotoran manusia saja. Kasus penyebaran penyakit cacingan oleh kotoran manusia dapat terjadi jika didukung oleh buruknya sanitasi lingkungan, seperti tidak tersedianya fasilitas jamban atau WC (Ginting, 2008). Perilaku BAB tidak di jamban serta kurangnya ketersediaan sumber air bersih adalah beberapa kondisi sebagai faktor risiko terjadinya penyakit cacingan (Astuty dkk, 2012). Sehingga perilaku BAB di sungai dan kebun dapat memperburuk kondisi sanitasi lingkungan, dengan memungkinkan tersebarnya telur cacing yang terkontaminasi pada kotoran (Ginting, 2008).

Perilaku BAB tidak di jamban dapat menyebabkan pencemaran tanah dan lingkungan oleh feses yang mengandung telur cacing adalah kondisi yang mendukung terjadinya penyakit cacingan (Astuty dkk, 2012). Penyebaran helminthiasis dapat melalui terkontaminasinya tanah dengan tinja (manusia dan hewan) yang mengandung telur cacing (Umar, 2008).

Keberadaan sumber air bersih sebagai air konsumsi harian juga harus dipastikan kelayakannya (Astuty dkk, 2012). Air yang baik adalah tidak berbau, berwarna, berasa, dan terjaga dari kotoran hewan yang bisa saja membawa penyebab penyakit seperti telur dan larva cacing (Ginting, 2008).

\section{Sanitasi Makanan Dan Minuman}

Pada kuesioner nomer 7, persentase jawaban benar responden sebesar 33\%. Dari hasil tersebut dapat disimpulkan bahwa $77 \%$ wali murid SDN 1, 2, 3, dan 4 Mulyoagung belum mengetahui bahwa sayur yang hanya dicuci tidak dapat menghilangkan seluruh cacing didalamnya. Penyakit cacingan dapat terjadi ketika seseorang mengkonsumsi sayur dan buah tanpa melalui proses dikupas, dicuci, dan dimasak dengan baik (Umar, 2008). Karena sayur yang hanya dicuci sebelum dikonsumsi, memungkinkan masih adanya telur atau larva cacing pada bagian dalam sayur, yang hanya bisa dimatikan melalui proses pemasakan (Andarumi, 2010).

WHO (2011) mengatakan bahwa kebiasaan menggunakan pupuk dari kotoran hewan pada lahan pertanian sayur, akan menyebabkan infeksi cacingan jika sayur tersebut tidak direbus (dimasak).

\section{Perilaku Kebersihan Diri}

Pada kuesioner nomer 5, persentase jawaban benar responden sebesar 49\%. Hal ini disimpulkan bahwa separuh dari wali murid SDN 1, 2, 3, dan 4 Mulyoagung belum mengetahui bahwa istirahat bukanlah faktor risko penyakit cacingan. Umar (2008) mengatakan bahwa anak usia sekolah dasar adalah usia paling rentan terkena penyakit cacingan. Anak usia sekolah dasar memiliki aktifitas tinggi, sehingga memiliki waktu istirahat yang lebih sedikit (Astuty dkk, 2012). Kurangnya waktu istirahat tersebut bukanlah menjadi faktor risiko penyakit cacingan pada anak, namun lebih kepada aktifitas fisik (bermain) anak yang tinggi dan cenderung untuk melakukan kontak dengan tanah (Faridan, 2013). Jika anak memiliki perilaku kebersihan diri yang kurang baik, maka hal tersebut menjadikan anak dapat terinfeksi penyakit cacingan (Sumanto, 2010).

Pada kuesioner nomer 8 dan 9, persentase jawaban benar responden sebesar $25 \%$. Hal ini dapat disimpulkan bahwa sebagian besar wali murid SDN 1, 2, 3, dan 4 Mulyoagung belum mengetahui kapan waktu yang tepat bagi anak untuk mencuci tangan. Perilaku mencuci tangan merupakan faktor risiko dari penyakit cacingan (Umar, 2008).

Kontak dengan tanah yang terkontaminasi dengan telur cacing, tanpa disertai perilaku mencuci tangan 
sebelum makan, setelah $\mathrm{BAB}$, dan setelah bermain diluar rumah sering menjadi cara penularan penyakit cacingan (Pasaribu, 2005).

WHO (2014) memberikan instruksi agar mencuci tangan sebelum makan dan setelah keluar rumah (bermain di luar rumah) untuk pencegahan terhadap infeksi cacingan diutamakan menggunakan sabun.

Faktor risiko lainnya selain mencuci tangan adalah melalui perilaku menjaga kebersihan kuku (Umar, 2008). Anak memiliki kecenderungan kontak dengan tanah yang terkontaminasi dengan telur cacing memungkinkan adanya telur dan larva cacing pada kuku tersebut (Pasaribu, 2005).

Pada kuesioner nomer 10, persentase jawaban benar responden sebesar 79\%. Hal ini dapat disimpulkan bahwa sebagian besar wali murid SDN 1, 2, 3, dan 4 Mulyoagung telah mengetahui bahwa bermain diluar rumah tanpa menggunakan alas kaki dapat menjadi faktor risiko terkena penyakit cacingan. Anak-anak memiliki kecenderungan untuk bermain diluar rumah pada lingkungan tanah terbuka tanpa menggunakan alas kaki, sehingga rentan terinfeksi STH (Sumanto, 2010). DEPKES RI (2008) memaparkan bahwa cacing yang hidupnya di tanah dapat menembus kulit anak-anak.

\section{Iklim dan Cuaca}

Pada kuesioner nomer 11 dan 12 , persentase jawaban benar responden sebesar 37\%. Hal ini dapat disimpulkan bahwa sebagian besar wali murid SDN 1, 2, 3, dan 4 Mulyoagung belum mengetahui bahwa iklim tropis dan musim penghujan dapat menjadi faktor risiko penyakit cacingan.

Menurut Sumanto (2010), bahwa penyakit cacingan tidak mudah menular di seluruh dunia dan hanya mudah menular pada negara dengan iklim tropis, karena cacing penyebab infeksi cacingan lebih banyak ditemukan di daerah lembab dan panas, atau beriklim tropis seperti Indonesia dan negara tropis lainnya. Sembiring
(2012) mengatakan bahwa pada negara yang tidak memiliki iklim tropis, telur dan larva cacing akan sulit berkembang biak.

Peningkatan angka prevalensi kejadian penyakit cacingan terjadi saat musim hujan, dimana curah hujan yang tinggi diikuti oleh kenaikan suhu udara dan tanah, sehingga mempercepat proses perkembangbiakan cacing parasit (Sembiring, 2012).

\section{Gejala dan Tanda Penyakit Cacingan Gejala Penyakit Cacingan}

Pada kuesioner nomer 13 dan 17, persentase jawaban benar responden sebesar $41 \%$. Hal ini disimpulkan bahwa wali murid SDN 1, 2, 3, dan 4 Mulyoagung sebagian telah mengetahui gejala anak yang menderita penyakit cacingan seperti lemah dan lesu, serta memiliki kondisi fisik seperti anak yang menderita kekurangan gizi.

Anak yang menderita helminthiasis biasanya lesu, tidak bergairah, dan kurang konsentrasi belajar (Umar, 2008). Hal tersebut dikarenakan penderita penyakit cacingan mengalami anemia atau kondisi kekurangan darah (Sumanto, 2010). Anemia yang terjadi dikarenakan cacing dalam usus menghisap darah penderitanya, sehingga dalam kondisi yang parah menyebabkan kekurangan darah (Ginting, 2008). Jika dilihat dari dampak jangka panjangnya, infeksi cacingan menimbulkan kerugian yang besar bagi penderita dan keluarga, seperti keadaan lemah dan lesu (Herdiman, 2007).

Helminthiasis merupakan penyakit yang diakibatkan oleh cacing dengan prevalensi tinggi, tidak mematikan tetapi menggerogoti kesehatan tubuh manusia sehingga berakibat menurunnya kondisi gizi, dan paling banyak menyerang anak-anak usia sekolah dasar (Umar, 2008). Pada kondisi yang lanjut, infeksi cacingan menyebabkan suatu kondisi berupa kekurangan gizi, berupa protein dan karbohidrat (DEPKES RI, 2004). 


\section{Tanda Penyakit Cacingan}

Pada kuesioner nomer 14, 15, dan 16, persentase jawaban benar responden sebesar $45 \%$. Hal ini dapat disimpulkan bahwa wali murid SDN 1, 2, 3, dan 4 Mulyoagung sebagian besar belum mengetahui tanda pada anak yang menderita penyakit cacingan.

Sembiring (2012) mengatakan bahwa larva cacing di paru-paru dapat menembus dinding pembuluh darah, lalu dinding alveolus, masuk rongga alveolus, kemudian naik ke trakea melalui bronkiolus dan bronkus, sehingga menimbulkan rangsangan pada faring dan merangsang penderita mengalami batuk yang berlangsung lama. Hal ini sejalan dengan apa yang dikatakan oleh Umar (2008) bahwa gejala infeksi cacingan adalah batuk yang berlangsung lama.

Sumanto (2010) mengatakan bahwa cacing ini menghisap darah

penderitanya, sehingga dapat menyebabkan anemia. Infeksi cacingan dapat menyebabkan kehilangan darah secara perlahan akibatnya pederita mengalami kondisi kekurangan darah merah atau anemia (DEPKES RI, 2004). Kondisi tersebut menyebabkan anak yang menderita helminthiasis biasanya lesu, tidak bergairah, dan kurang konsentrasi belajar (Umar, 2008).

Infeksi faring menyebabkan batuk berlangsung lama (Sembiring, 2012) dan infeksi usus akibat cacing menghisap darah pada dinding usus

penderita (Sumanto, 2010), menyebabkan anak mengalami suhu tubuh yang meningkat. Sehingga pada anak yang menderita penyakit cacingan lanjut, akan mengalami suhu tubuh yang panas.

\section{Patofisiologi atau Penularan Penyakit Cacingan}

Pada kuesioner nomer 3, persentase jawaban benar responden sebesar 63\%. Hasil tersebut dapat disimpulkan bahwa sebagian besar wali murid SDN 1, 2, 3, dan 4 Mulyoagung telah mengetahui bahwa cacing dan telur cacing dapat masuk menembus kulit anak-anak. DEPKES RI (2008) memaparkan bahwa proses masuknya cacing dari tanah bisa terjadi karena cacing di tanah dapat menembus kulit anak-anak saat bermain di tanah terbuka tanpa menggunakan alas kaki.

Pada kuesioner item nomer 2, 4, dan 18, persentase jawaban benar responden sebesar 48\%. Hal ini dapat disimpulkan bahwa sebagian besar dari wali murid SDN 1, 2, 3, dan 4

Mulyoagung belum mengetahui mekanisme telur dan larva cacing masuk kedalam organ pernafasan, serta dahak dapat mengandung telur dan larva cacing.

Ginting (2008) mengatakan bahwa cacing yang menembus kulit akan masuk ke aliran darah, lalu menuju jantung kanan, kemudian ke paru-paru, dan berkembang biak di paru-paru lalu menuju usus halus saat dewasa. Setelah telur menetas di dalam paru-paru, larva cacing akan naik untuk berimigrasi kembali ke usus halus, dimana pada kondisi ini penderita akan mengalami batuk disertai dahak yang berdarah dan kadang berisi larva cacing yang dapat hidup hingga 8 hari pada kondisi lembab (WHO, 2016).

Pada item kuesioner nomer 19, persentase jawaban benar responden sebesar 54\%. Hasil ini dapat disimpulkan bahwa wali murid SDN 1, 2, 3, dan 4 Mulyoagung sebagian besar telah mengetahui bahwa bermain bersama anak penderita cacingan tidak dapat tertularkan penyakit cacingan. STH adalah penyakit yang ditularkan melalui tanah yang dapat disebarkan melalui hewan, makanan dan minuman serta perilaku kebersihan diri yang buruk (Umar, 2008).

\section{Penatalaksanaan Penyakit Cacingan Penentuan Diagnosis}

Pada kuesioner nomer 20, persentase jawaban benar responden sebesar 34\%. Hal ini disimpulkan bahwa sebagian besar wali murid SDN 1, 2, 3, dan 4 Mulyoagung cenderung belum mengetahui bahwa uji laboratorium 
darah bukanlah teknik diagnosis penyakit cacingan.

Sandjaja (2007) mengatakan jika diagnosa cacingan dapat ditegakkan dengan menemukan telur cacing dan cacing dewasa melalui kotoran. Pasaribu (2005) menambahkan jika diagnosis cacingan dapat ditegakkan melalui pemeriksaan kualitatif telur cacing pada sediaan tinja segar.

\section{Pengobatan}

Pada kuesioner nomer 21, persentase jawaban benar responden sebesar 50\%. Hal ini disimpulkan bahwa separuh dari wali murid SDN 1, 2, 3, dan 4 Mulyoagung sebagian telah mengetahui bahwa untuk mendapatkan obat cacing di apotek tidak diharuskan menggunakan resep dari dokter.

Pengobatan penyakit cacingan dapat berbeda-beda tergantung jenis cacing yang menyebabkan penyakit (Sembiring, 2012). Untuk Obat berupa

Mebendazol, Pirantel Pamoat, Levamisol, dan Piperazin yang diperuntukkan obat cacing secara umum dapat dibeli di apotek pada berbagai macam merk dagang, namun pada kasus cacing pita memerlukan terapi dengan golongan obat keras yang hanya dapat diperoleh dengan resep dokter (BPOM RI, 2012). Hotez dkk (2013) mengatakan bahwa Major Global Helminthic Desease Control Initiatives memiliki target pemenuhan obat cacingan pada anak berupa albendazole dan mebendazole pada tahun 2020.

\section{Pencegahan Penyakit Cacingan}

Pada kuesioner nomer 22, persentase jawaban benar responden sebesar 9\%. Hal ini dapat disimpulkan bahwa hanya sedikit wali murid SDN 1, 2, 3, dan 4 Mulyoagung yang mengetahui bahwa mencuci piring makan dapat mencegah terjangkitnya penyakit cacingan.

\section{KESIMPULAN}

Berdasarkan hasil dan pembahasan penelitian, maka dapat diambil kesimpulan bahwa gambaran pengetahuan penyakit cacingan (helminthiasis) pada wali murid SDN 1, 2, 3, dan 4 Mulyoagung, Kecamatan Dau, Kabupaten Malang, Jawa Timur secara umum adalah kurang. Hasil ini diperoleh dari hasil perhitungan rata-rata skor responden yakni sebesar 45,81. Rentang skor responden paling rendah adalah 18 (benar 4) dan skor paling tinggi adalah 68 (benar 15), serta skor paling banyak adalah 50 (benar 11) sebanyak 59 responden.

Hasil tersebut jika dilihat berdasarkan tingkat pengetahuan responden pada aspek penyebab penyakit cacingan, responden memiliki pengetahuan cukup baik, dengan persentase jawaban benar sebesar $58,7 \%$, pada aspek faktor risiko penyakit cacingan, responden memiliki pengetahuan kurang, dengan persentase jawaban benar sebesar 46,3\%, pada aspek gejala dan tanda penyakit

cacingan, responden memiliki pengetahuan kurang, dengan persentase jawaban benar sebesar 50,5\%, pada aspek patofisiologi atau penularan penyakit cacingan, responden memiliki pengetahuan cukup baik, dengan persentase jawaban benar sebesar 57\%, pada aspek penatalaksanaan penyakit cacingan responden memiliki pengetahuan kurang, dengan persentase jawaban benar sebesar $42 \%$, dan pada aspek pencegahan penyakit cacingan, responden memiliki pengetahuan kurang, dengan persentase jawaban benar sebesar $9 \%$.

\section{SARAN}

Perlu dilakukan sosialisasi dan promosi kesehatan untuk meningkatkan pengetahuan penyakit cacingan di Kecamatan Dau, dengan sasaran khususnya kepada orang tua yang memiliki anak usia dibawah 12 tahun. Kemudian perlu dilakukan pelatihan perilaku hidup bersih dan sehat untuk anak sekolah se-Kecamatan Dau dan pengawasan fasilitas penunjang perilaku hidup bersih dan sehat tersebut di sekolah dasar se-Kecamatan Dau. 
Perlu adanya pengadaan fasilitas untuk cuci tangan beserta sabun untuk cuci tangan di setiap kelas, kantin sekolah, dan toilet. Kemudian perlu dilakukan pelarangan pedagang jajanan dari luar sekolah untuk berjualan di lingkungan sekolah serta meningkatkan kebersihan dan kesehatan makanan dan minuman yang dijual di kantin sekolah.

Perlu menempatkan mahasiswa PBL komunitas di Kecamatan Dau, khususnya di Desa Mulyoagung dan melakukan kerjasama instansi dengan

Puskesmas Dau dalam promosi kesehatan penyakit cacingan baik kepada orang tua maupun anak di sekolah dasar di Kecamatan Dau, Kabupaten Malang, Jawa Timur.

Perlu adanya penelitian mengenai angka kejadian penyakit cacingan khususnya di Desa Mulyoagung dan umunya di Kecamatan Dau.

\section{DAFTAR RUJUKAN}

Andarumi, A. 2010. Gambaran Faktorfaktor Penyebab Infeksi Cacingan pada anak di SDN 01 Pasirlangu Cisarua. Bogor. (Online), (Error! Hyperlink reference not valid.) diakses 29 Oktober 2016.

Arikunto, S. 2007. Prosedur Penelitian Suatu Pendekatan Praktik edisi revisi VI. Jakarta: Rineka Cipta.

Astuty H, Mulyati, dan Winita. 2012. Upaya Pemberantasan Kecacingan di Sekolah Dasar. Makara, Jurnal Kesehatan, Vol. 16, No. 2 hal:65-71. Jakarta: Departemen Parasitologi, Fakultas Kedokteran, Universitas Indonesia.

BADAN POM RI. 2012. Seri Swamedikasi 4 "Obat Kecacingan". (Online), (http://bpom.go.id) diakses 2 November 2016.

Departemen Kesehatan RI. 2004. Pedoman Umum Program Nasional Pemberantasan Cacingan di Era Desentralisi. Jakarta: Subdit Diare dan
Penyakit Pencernaan Ditjen

PPM \& PLP Depkes RI.

Departemen Kesehatan RI. 2005.

Laporan Hasil Survei

Morbiditas Cacingan Tahun

2005. Jakarta: Subdit Diare dan

Penyakit Pencernaan Ditjen

PPM \& PLP Depkes RI.

Depkes RI. 2006. Profil Kesehatan Indonesia. (Online), (Error? Hyperlink reference not valid.) diakses 19 Januari 2015.

Depkes RI. 2008. Profil Kesehatan Indonesia. (Online), (Error! Hyperlink reference not valid.) diakses 20

September 2016.

Faridan K, dkk. 2013. Faktor-faktor yang berhubungan dengan kejadian kecacingan pada sisa Sekolah Dasar Negeri Cempaka 1 Kota Banjarbaru. (Online), (http://ejournal.litbang.depkes.g o.id/index.php/buski/article /view/3229/3200) diakses 17 Juli 2016.

Ginting, A. 2008. Faktor-Faktor Yang Berhubungan Dengan Kejadian Kecacingan Pada Anak Sekolah Dasar Di Desa Tertinggal Kecamatan Pangaruran Kabupaten Samosir. (Online), (Error! Hyperlink reference not valid.) diakses 22 Agustus 2016.

Ginting, SA. 2003. Hubungan Antara Status Sosial Ekonomi DenganKejadian Kecacingan Pada Anak Sekolah Dasar Di Desa Suka Kecamatan Tiga Panah Kabupaten Karo Sumatra Utara. (Online), (Error!

Hyperlink reference not valid.) diakses 27 September 2016.

Herdiman. 2007. Penyakit Cacingan Yang Ditularkan Melalui Tanah. Jakarta: Pusat Penerbit Ilmu Penyakit Dalam FKUI.

Hotez P.J, et al. 2008. Helminth Infections: The Great Neglacted Tropical Deseases. (Online), (http://search.proquest.com/docv 
iew/200561377/

fulltextPDF/B5CC6ECF10D740

FFPQ/20?accountid38628)diaks

es 16 April 2017.

Notoatmodjo, S. 2010. Ilmu Perilaku

Kesehatan. Jakarta: Rineka

Cipta.

Notoatmodjo, S. 2012. Promosi

Kesehatan Dan Perilaku

Kesehatan. Jakarta:

Rineka Cipta.

Notoatmodjo, S. 2012. Metodologi

Penelitian Kesehatan.

Jakarta: Rineka Cipta.

Pasaribu, HER. 2005. Perbandingan

Penyuluhan Kesehatan Metode

Ceramah Tanya Jawab Dengan

Penyuluhan Kesehatan

Menggunakan Buku Kecacingan

Dalam Mencegah Reinfeksi

Ascaris lumbricoides Pada Anak

Sekolah Dasar. (Online),

(http://eprints.undip.ac.id/17659/

1/Hotber_ER_Pasaribu.pdf)

diakses 20 Oktober 2016.

Sandjaya B. 2007. Helminthologi

Kesehatan. Jakarta; Prestasi

Pustaka.

Sembiring, B. 2012. Pengaruh Sosio Budaya Dan Dukungan Keluarga Terhadap Pencegahan Infeksi Kecacingan Pada Anak Sekolah Dasar Negeri 05 Di

Kecamatan Kuala Kabupaten Langkat. (Online), (Error! Hyperlink reference not valid.) diakses 10 September 2016.

Sumanto, D. 2010. Faktor Risiko Infeksi Cacing Tambang Pada Anak Sekolah (Studi kasus kontrol di Desa Rejosari, Karangawen, Demak). (Online), http://eprints.undip.ac.id/23985/

1/DIDIK_SUMANTO.pdf

diakses 22 Desember 2015.

Umar, Z. 2008. Perilaku Cuci Tangan

Sebelum Makan Dan

Kecacingan Pada Murid SD di

Kabupaten Pesisir Selatan

Sumatra Barat. Jurnal

Kesehatan Masyarakat Nasional vol. 2 no. 6 Juni 2008.

UNDP. 2011. Human Development

Index. (Online), (Error!

Hyperlink reference not valid.) diakses 6 Oktober 2016.

WHO. 2011. Worm Control. (Online), (http://www.who.int/mediacentr e /factsheets/fs366/en) diakses 16 September 2016.

WHO. 2011. International Conference of Social Determinants of Health. (Online),

(http://www.who.int/social_dete rminants/Background-paperfinal.pdf) diakses 13 April 2017.

WHO. 2014. Intestinal Worm. (Online), (http://www.who.int/intestinal worms /resources/en/ppc_unicef_finalre port.pdf) diakses 1 November 2016.

WHO. 2016. Soil Transmitted Helminths Infection. (Online), (Error!

Hyperlink reference not

valid.) diakses 16

September 2016.

WHO. 2017. Ottawa Charter, The First International Conference of Health. (Online),

(http://www.who.int/healthprom otion/conferences /previous /ottawa/en/) diakses 13 April 2017 